\title{
Back to the spring of 2020: facts and hope of COVID-19 outbreak
}

\author{
Guangbiao Zhou $(\bowtie)^{1}$, Saijuan Chen $(\bowtie)^{2}$, Zhu Chen $^{2}$ \\ ${ }^{1}$ State Key Laboratory of Molecular Oncology, National Cancer Center/National Clinical Research Center for Cancer/Cancer Hospital, \\ Chinese Academy of Medical Sciences and Peking Union Medical College, Beijing 100021, China; ${ }^{2}$ State Key Laboratory of Medical \\ Genomics, Shanghai Institute of Hematology, National Research Center for Translational Medicine (Shanghai), Ruijin Hospital Affiliated to \\ Shanghai Jiao Tong University School of Medicine, Shanghai 200025, China
}

(c) Higher Education Press and Springer-Verlag GmbH Germany, part of Springer Nature 2020

Since December 2019, an atypical pneumonia has occurred in Wuhan, a beautiful city located at the center of China (Fig. 1), and the whole country. The origin of the disease remains unclear and the suspected Huanan Seafood Wholesale Market was closed on January 1, 2020. Very rapidly, a novel coronavirus was isolated and named first the 2019 novel coronavirus (2019-nCoV) [1] and subsequently severe acute respiratory syndrome coronavirus 2 (SARS-CoV-2) [2], and is suggested to be named as human coronavirus 2019 (HCoV-19) [3]. Meanwhile, the disease is chronologically called pneumonia of unknown origin, novel coronavirus pneumonia (NCP), and coronavirus disease-2019 (COVID-19) (Fig. 2). Superspreading events of this virus have also taken place on the Diamond Princess cruise off the coast of Yokohama, Japan [4]. The Chinese central [5] and local governments [6] have been endeavoring unprecedented efforts to constrain the outbreak, and more than 30000 medical professionals especially doctors and nurses outside Wuhan have been joining the local ones to handle this emergency.

\section{Epidemiology and clinical characteristics}

In early December 2019, the first case was reported; by December 31, 104 cases were diagnosed [7]. The disease took 30 days to spread to all the 34 provinces/regions (including Hong Kong, Macao, and Taiwan) of China. The number of confirmed cases of COVID-19 rose to 11791 in Chinese mainland as of January 31, including 259 deaths.

Received February 21, 2020

Correspondence: Guangbiao Zhou, gbzhou@cicams.ac.cn; Saijuan Chen, sjchen@stn.sh.cn
The confirmed cases increased rapidly, and by February 21, 75567 confirmed cases, 5206 suspected cases, and 2239 deaths, have been reported in China. The disease also occurred in 26 countries, with 1151 confirmed cases and 8 deaths reported by February 21 [8]. By February 21, severe cases in Wuhan, other regions of China, and the whole country were $9628(21.2 \%), 2005(6.6 \%)$, and 11633 $(15.4 \%)$, respectively (Table 1$)$. The reproduction number $\left(\mathrm{R}_{0}\right)$ is between 2.2 and $4.8[9,10]$.

The commonest symptoms of the COVID-19 include

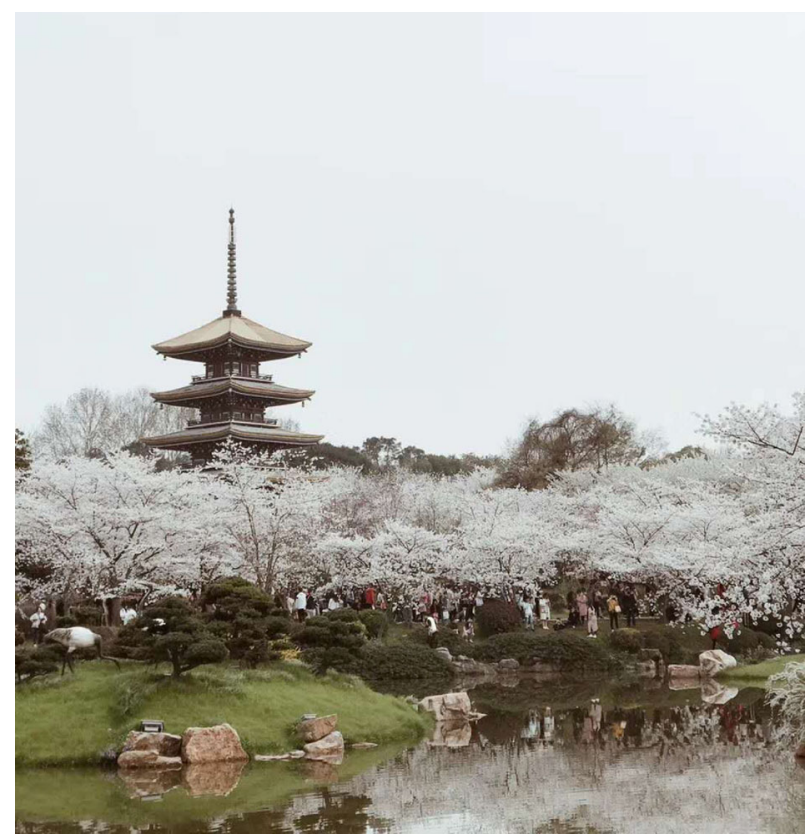

Fig. 1 Back to the spring of 2020. Sakura garden of East Lake, Wuhan, 2019. Courtesy of Mr. Zhenyin Chen, a postgraduate student of Guizhou University. 


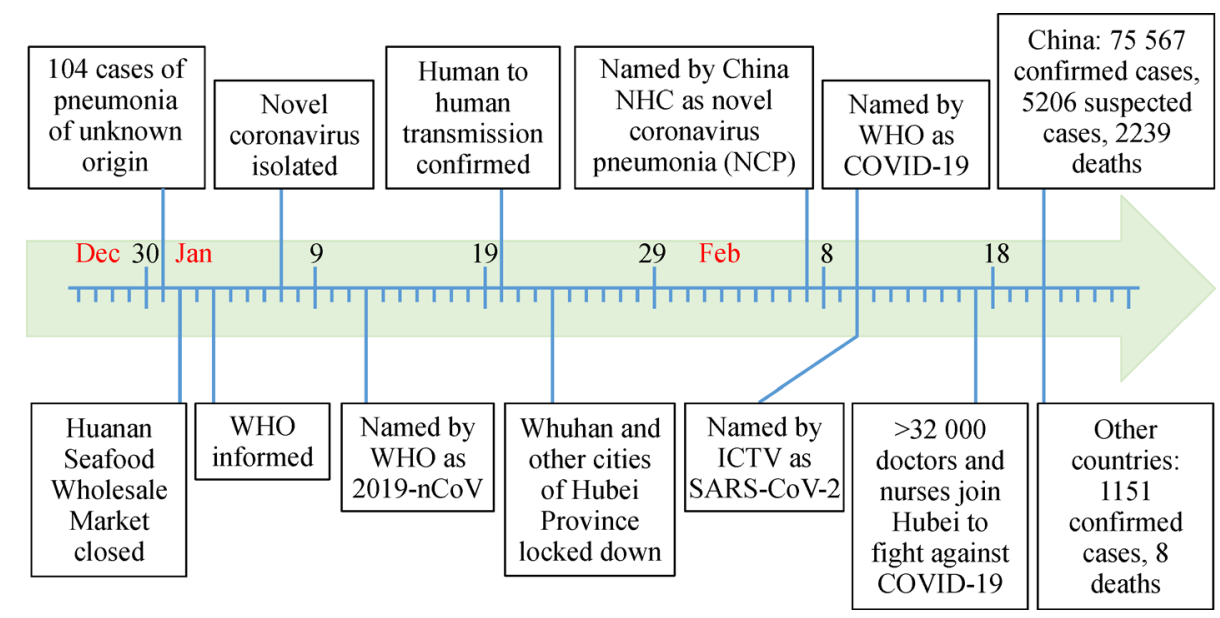

Fig. 2 A brief timeline of the COVID-19 outbreak. ICTV, International Committee on Taxonomy of Viruses; NHC, National Health Commission; WHO, World Health Organization.

Table 1 Comparison of disease severity and mortality in patients from different regions or countries

\begin{tabular}{lllll}
\hline & \multicolumn{2}{c}{ China } & \multirow{2}{*}{ Other countries } \\
\cline { 2 - 5 } & Wuhan & Other regions & Total & 1151 \\
Total cases* & 45346 & 30221 & 75567 & - \\
Disease severity & & & & \\
Non-severe, $n(\%)$ & $34034(75.1 \%)$ & $27661(91.5 \%)$ & $61695(81.6 \%)$ & - \\
Severe, $n(\%)$ & $9628(21.2 \%)$ & $2005(6.6 \%)$ & $11633(15.4 \%)$ & $8(0.6 \%)$ \\
Mortality, $n(\%)$ & $1684(3.7 \%)$ & $555(1.8 \%)$ & $2239(3.0 \%)$ & \\
\hline
\end{tabular}

*The data were collected from the National Health Commission, P.R. China and World Health Organization. Date of assess: February 21, 2020.

fever, dry cough, fatigue, sputum, and shortness of breath, with a small proportion of patients $(889 / 72314,1.2 \%)$ as asymptomatic and probably spreaders [7]. Cytokine storm that is induced by virus particles, is associated with disease severity [11,12]. A first histological examination of COVID-19 patient showed diffuse alveolar damage with cellular fibromyxoid exudates, desquamation of pneumocytes and hyaline membrane formation, pulmonary edema with hyaline membrane formation, interstitial mononuclear inflammatory infiltrates, and multinucleated syncytial cells with atypical enlarged pneumocytes in the lungs [13]. These results shed insights into the pathogenesis of COVID-19 and may help design therapeutic strategies against the disease.

\section{The virus}

A previously unknown betacoronavirus was discovered from bronchoalveolar-lavage fluid samples of the patients, which is the seventh member of the family of coronaviruses that infect humans $[1,14]$. The virus was most closely related to a group of SARS-like coronaviruses (genus Betacoronavirus, subgenus Sarbecovirus) previously sampled from bats in China [14,15], and a virus with $99 \%$ sequence homology to the receptor-binding domain (RBD) and 90\% to the SARS-CoV-2 genome was also found in Malayan pangolins in southern China [16]. However, higher viral loads were detected in the nose than in the throat of symptomatic and asymptomatic COVID19 , a pattern resembling that of influenza but not SARS$\mathrm{CoV}$ [17]. Human angiotensin-converting enzyme 2 (ACE2) has been shown to be the putative receptor for the virus to enter into host cells $[15,18]$, and biophysical and structural evidence shows that the SARS-CoV-2 spike glycoprotein binds ACE2 with high affinity [19]. ACE2 can also bind spike protein through association with B0AT1 [20]. ACE2 locates on the organs such as lung, heart, esophagus, kidney, bladder and ileum, and in particular on the cell types such as type II alveolar cells, myocardial cells, proximal tubule cells of kidney, ileum and esophagus epithelial cells, and bladder urothelial cells, providing clues for further investigating the pathogenesis COVID-19 [21].

\section{Therapeutic strategies}

So far, neither drug nor vaccine has been approved to treat the novel COVID-19. While supportive treatment regimens including oxygen therapy are widely used, antivirus (oseltamivir) and anti-HIV (lopinavir/ritonavir) drugs are 
also applied in treating COVID-19. Some emerging therapeutics are being tested in clinical trials. For example, virally targeted agents, approved nucleoside analogs (favipiravir and ribavirin) and experimental nucleoside analogs (remdesivir and galidesivir), may have potentials against SARS-CoV-2 [22]. Remdesivir has been shown to be able to block virus infection [23] and exert therapeutic efficacy in the first COVID-19 case in the United States [24]. Two phase III trials have been initiated to evaluate remdesivir in COVID-19. Anti-malaria drug chloroquine shows activity in blocking SARS-CoV-2 infection [23] and is being evaluated in an open-label trial [22]. Convalescent patient plasma that contain anti-SARS-CoV-2 antibody holds promise to beat this disease [25]. ACE2 and Spike protein represent two novel therapeutic targets for the disease. An ongoing study using Tocilizumab, a specific monoclonal antibody antagonist of interleukin- 6 receptor (IL-6R) which proved to be effective in alleviating cytokine release syndrome, showed preliminary positive effects [26].

Traditional Chinese medicine (TCM) plays an active role in fighting infectious disease, exemplified by ancient formula Maxingshigan-Yinqiaosan in the treatment of H1N1 influenza [27]. In combination with Western medicine [28] or used alone, TCM is widely applied or being evaluated in clinical trials to treat COVID-19.

\section{Hope and perspectives}

Two and a half months have witnessed the great efforts that China has been endeavoring to control the outbreak of the COVID-19. These include lockdown of Wuhan and related cities, control of population mobility, and input of huge resource to the regions. China races against the clock to build virus hospitals, including Huoshenshan Hospital with 1000 beds built in 9 days and Leishenshan Hospital with 1500 beds completed in 15 days. More than 15 Fangcang hospitals (with large open space and necessary anti-infection conditions) have been built with a capacity of more than 20000 beds for the isolation and treatment of the patients. The updated genome sequence of SARS-CoV2 has been shared to the public, clinical trials are undergoing, and scientists from China and overseas are working together to combat this public health emergency. With great contributions of our domestic selfless medical professionals and supports from public health scientists around the world [29], by using smart but firm public health measures preventing spreadout of the virus and more specific combinatorial therapeutic strategies, such as the anti-viral convalescent plasma and drugs against cytokine storm for severe cases, as well as effective TCM drugs and technologies, we believe that the mankind will win this battle, and Wuhan will be back to the spring.

\section{Compliance with ethics guidelines}

Guangbiao Zhou, Saijuan Chen, and Zhu Chen declare no conflict of interests. This manuscript does not involve a research protocol requiring approval by the relevant institutional review board or ethics committee.

\section{References}

1. Zhu N, Zhang D, Wang W, Li X, Yang B, Song J, Zhao X, Huang B, Shi W, Lu R, Niu P, Zhan F, Ma X, Wang D, Xu W, Wu G, Gao GF, Tan W; China Novel Coronavirus Investigating and Research Team. A novel coronavirus from patients with pneumonia in China, 2019. N Engl J Med 2020; 382(8): 727-733

2. Gorbalenya AE, Baker SC, Baric RS, de Groot RJ, Drosten C, Gulyaeva AA, et al. Severe acute respiratory syndromerelated coronavirus: the species and its viruses - a statement of the Coronavirus Study Group. bioRxiv 2020; doi: 10.1101/ 2020.02.07.937862

3. Jiang S, Shi Z, Shu Y, Song J, Gao GF, Tan W, Guo D. A distinct name is needed for the new coronavirus. Lancet $2020 \mathrm{Feb} 19$. [Epub ahead of print] doi: 10.1016/S0140-6736(20)30419-0

4. Cowling BJ, Leung GM. Epidemiological research priorities for public health control of the ongoing global novel coronavirus (2019nCoV) outbreak. Euro Surveill 2020; 25(6): 2000110

5. Wang C, Horby PW, Hayden FG, Gao GF. A novel coronavirus outbreak of global health concern. Lancet 2020; 395(10223): 470473

6. Gong FH, Xiong Y, Xiao J, Lin L, Liu XD, Wang DZ, Li XK. China's local governments are combating COVID-19 with unprecedented responses - from a Wenzhou governance perspective. Front Med 2020 Feb 13. [Epub ahead of print] doi: 10.1007/s11684020-0755-Z

7. Novel Coronavirus Pneumonia Emergency Response Epidemiology Team. The epidemiological characteristics of an outbreak of 2019 novel coronavirus diseases (COVID-19) in China. Chin J Epidemiol (Zhonghua Liu Xing Bing Xue Za Zhi) 2020; 41(2): 145-151 (in Chinese)

8. World Health Organization. Coronavirus disease 2019 (COVID-19) Situation Report - 29. 2020

9. Anastassopoulou C, Russo L, Tsakris A, Siettos C. Databased analysis, modelling and forecasting of the novel coronavirus (2019-nCoV) outbreak. medRxiv 2020; doi: 10.1101/ 2020.02.11.20022186

10. Li Q, Guan X, Wu P, Wang X, Zhou L, Tong Y, Ren R, Leung KSM, Lau EHY, Wong JY, Xing X, Xiang N, Wu Y, Li C, Chen Q, Li D, Liu T, Zhao J, Liu M, Tu W, Chen C, Jin L, Yang R, Wang Q, Zhou S, Wang R, Liu H, Luo Y, Liu Y, Shao G, Li H, Tao Z, Yang Y, Deng Z, Liu B, Ma Z, Zhang Y, Shi G, Lam TTY, Wu JTK, Gao GF, Cowling BJ, Yang B, Leung GM, Feng Z. Early transmission dynamics in Wuhan, China, of novel coronavirus-infected pneumonia. N Engl J Med 2020 Jan 29. [Epub ahead of print] doi: 10.1056/ NEJMoa2001316

11. Huang C, Wang Y, Li X, Ren L, Zhao J, Hu Y, Zhang L, Fan G, Xu J, Gu X, Cheng Z, Yu T, Xia J, Wei Y, Wu W, Xie X, Yin W, Li H, 
Liu M, Xiao Y, Gao H, Guo L, Xie J, Wang G, Jiang R, Gao Z, Jin Q, Wang J, Cao B. Clinical features of patients infected with 2019 novel coronavirus in Wuhan, China. Lancet 2020; 395(10223): 497 506

12. Chen N, Zhou M, Dong X, Qu J, Gong F, Han Y, Qiu Y, Wang J, Liu Y, Wei Y, Xia J, Yu T, Zhang X, Zhang L. Epidemiological and clinical characteristics of 99 cases of 2019 novel coronavirus pneumonia in Wuhan, China: a descriptive study. Lancet 2020; 395 (10223): 507-513

13. Xu Z, Shi L, Wang Y, Zhang J, Huang L, Zhang C, Liu S, Zhao P, Liu H, Zhu L, Tai Y, Bai C, Gao T, Song J, Xia P, Dong J, Zhao J, Wang FS. Pathological findings of COVID-19 associated with acute respiratory distress syndrome. Lancet Respir Med 2020 Feb 18. [Epub ahead of print] doi: 10.1016/S2213-2600(20)30076-X

14. Lu R, Zhao X, Li J, Niu P, Yang B, Wu H, Wang W, Song H, Huang B, Zhu N, Bi Y, Ma X, Zhan F, Wang L, Hu T, Zhou H, Hu Z, Zhou W, Zhao L, Chen J, Meng Y, Wang J, Lin Y, Yuan J, Xie Z, Ma J, Liu WJ, Wang D, Xu W, Holmes EC, Gao GF, Wu G, Chen W, Shi W, Tan W. Genomic characterisation and epidemiology of 2019 novel coronavirus: implications for virus origins and receptor binding. Lancet 2020; 395(10224): 565-574

15. Zhou P, Yang XL, Wang XG, Hu B, Zhang L, Zhang W, Si HR, Zhu Y, Li B, Huang CL, Chen HD, Chen J, Luo Y, Guo H, Jiang RD, Liu MQ, Chen Y, Shen XR, Wang X, Zheng XS, Zhao K, Chen QJ, Deng F, Liu LL, Yan B, Zhan FX, Wang YY, Xiao GF, Shi ZL. A pneumonia outbreak associated with a new coronavirus of probable bat origin. Nature 2020 Feb 3. [Epub ahead of print] doi: 10.1038/ s41586-020-2012-7

16. Lam TTY, Shum MHH, Zhu HC, Tong YG, Ni XB, Liao YS, et al. Identification of 2019-nCoV related coronaviruses in Malayan pangolins in southern China. bioRxiv 2020; doi:10.1101/ 2020.02.13.945485

17. Zou L, Ruan F, Huang M, Liang L, Huang H, Hong Z, Yu J, Kang M, Song Y, Xia J, Guo Q, Song T, He J, Yen HL, Peiris M, Wu J. SARS-CoV-2 viral load in upper respiratory specimens of infected patients. N Engl J Med 2020 Feb 19. [Epub ahead of print] doi: 10.1056/NEJMc2001737

18. Letko M, Munster V. Functional assessment of cell entry and receptor usage for lineage B $\beta$-coronaviruses, including 2019-nCoV. bioRxiv 2020; doi: 10.1101/2020.01.22.915660

19. Wrapp D, Wang N, Corbett KS, Goldsmith JA, Hsieh CL, Abiona O, Graham BS, McLellan JS. Cryo-EM structure of the 2019-nCoV spike in the prefusion conformation. Science $2020 \mathrm{Feb} 19$. [Epub ahead of print] doi: 10.1126/science.abb2507

20. Zhou Q, Yan R, Zhang Y, Li Y, Xia L. Structure of dimeric fulllength human ACE2 in complex with $\mathrm{B}^{0} \mathrm{AT} 1$. bioRxiv 2020; doi:
$10.1101 / 2020.02 .17 .951848$

21. Zou X, Chen K, Zou JW, Han PY, Hao J, Han ZG. The single-cell RNA-seq data analysis on the receptor ACE2 expression reveals the potential risk of different human organs vulnerable to 2019-nCoV infection. Front Med 2020 Feb 8. [Epub ahead of print] doi: 10.1007/s11684-020-0754-0

22. Li G, De Clercq E. Therapeutic options for the 2019 novel coronavirus (2019-nCoV). Nat Rev Drug Disc 2020 Feb 10. [Epub ahead of print] doi: 10.1038/d41573-020-00016-0

23. Wang M, Cao R, Zhang L, Yang X, Liu J, Xu M, Shi Z, Hu Z, Zhong W, Xiao G. Remdesivir and chloroquine effectively inhibit the recently emerged novel coronavirus (2019-nCoV) in vitro. Cell Res 2020 Feb 4. [Epub ahead of print] doi: 10.1038/s41422-0200282-0

24. Holshue ML, DeBolt C, Lindquist S, Lofy KH, Wiesman J, Bruce H, Spitters C, Ericson K, Wilkerson S, Tural A, Diaz G, Cohn A, Fox L, Patel A, Gerber SI, Kim L, Tong S, Lu X, Lindstrom S, Pallansch MA, Weldon WC, Biggs HM, Uyeki TM, Pillai SK; Washington State 2019-nCoV Case Investigation Team. First case of 2019 novel coronavirus in the United States. N Engl J Med 2020 Jan 31. [Epub ahead of print] doi: 10.1056/NEJMoa2001191

25. Zhang Y, Wang X. 32 recovered patients donate plasma to others with coronavirus infection. China Daily 2020 Feb 16. https://www. chinadaily.com.cn/a/202002/16/WS5e48cbf6a310128217277d72. html

26. Zhang Y. Scientists target major cause of critically ill virus deaths. China Daily 2020 Feb 15. https://www.chinadaily.com.cn/a/202002/ 15/WS5e47c280a310128217277ca0.html

27. Wang C, Cao B, Liu QQ, Zou ZQ, Liang ZA, Gu L, Dong JP, Liang LR, Li XW, Hu K, He XS, Sun YH, An Y, Yang T, Cao ZX, Guo YM, Wen XM, Wang YG, Liu YL, Jiang LD. Oseltamivir compared with the Chinese traditional therapy maxingshigan-yinqiaosan in the treatment of H1N1 influenza: a randomized trial. Ann Intern Med 2011; 155(4): 217-225

28. Ni L, Zhou L, Zhou M, Zhao J, Wang D. Combination of western medicine and Chinese patent medicine in treating a family case of COVID-19. Front Med 2020 Feb 19. [Epub ahead of print] doi: 10.1007/s11684-020-0757-x

29. Calisher C, Carroll D, Colwell R, Corley RB, Daszak P, Drosten C, Enjuanes L, Farrar J, Field H, Golding J, Gorbalenya A, Haagmans B, Hughes JM, Karesh WB, Keusch GT, Lam SK, Lubroth J, Mackenzie JS, Madoff L, Mazet J, Palese P, Perlman S, Poon L, Roizman B, Saif L, Subbarao K, Turner M. Statement in support of the scientists, public health professionals, and medical professionals of China combatting COVID-19. Lancet 2020 Feb 19. [Epub ahead of print] doi: 10.1016/S0140-6736(20)30418-9 